\title{
Vertical pattern, geochemical composition and sedimentation of a sediment core in the western Ulleung Basin, Korea
}

\author{
SEOK-Hwi Hong ${ }^{1}$, In KwON UM ${ }^{1}$, GwANG-Soo LEE ${ }^{1}$ \\ ${ }^{1} 124$ Gwahak-ro, Yuseong-gu, Daejeon 34132, Korea, \\ shhong@kigam.re.kr
}

X-ray fluorescence (XRF) scanning of discrete samples provides a time- and cost-efficient alternative to conventional geochemical analyses of discretely sampled paleoenvironmental archives. In order to determine the relationship between lithostratigraphy and geochemistry of a core sediment using a XRF core scanner, a piston core collected on a shelf margin of the western Ulleung Basin of Korea was examined. XRF elemental analysis was performed on each sample to determine the change in the elemental composition of the piston core sediemtns by depth. The measured values for a total of 28 elements were determined. Among them, $\mathrm{Ca} / \mathrm{Fe}, \mathrm{Sr} / \mathrm{Ca}, \mathrm{Zr} / \mathrm{Rb}$, $\mathrm{Ti} / \mathrm{Rb}$, and $\mathrm{Fe} / \mathrm{Ti}$, which are proxies for determine the changes between lithostratigraphy and geochemistry, are illustrated. Overall, $\mathrm{Sr} / \mathrm{Ca}, \mathrm{Zr} / \mathrm{Rb}$ and $\mathrm{Ti} / \mathrm{Rb}$ values show positive or negative correlations with decreasing and increasing mean grain size. This makes it possible to distinguish between the marine and terristrial processes. In addition, when there are small shell fragments in the sediments, $\mathrm{Ca} / \mathrm{Fe}$ and $\mathrm{Sr} / \mathrm{Ca}$ values show distinct opposite trends. Therefore, $\mathrm{Ca} / \mathrm{Fe}, \mathrm{Sr} / \mathrm{Ca}, \mathrm{Fe} / \mathrm{Ti}, \mathrm{Zr} / \mathrm{Rb}, \mathrm{Ti} / \mathrm{Rb}$ data make it possible to distinguish between marine and terristrial sediment inputs. However, in some invervals, the relationships was not clear tendency. Thus, a combination of the elements is required for accurate indication of the sediments on a shelf margin of the western Ulleung Basin, Korea. 